\title{
PEMIKIRAN POLITIK SAYYID QUTB TENTANG PEMERINTAHAN ISLAM
}

Badarussyamsi

Fakultas Ushuluddin IAIN STS Jambi

\begin{abstract}
Abstrak: Artikel ini membahas pemikiran politik Sayyid Qutb mengenai Pemerintahan Islam. Wacana ini tergolong wacana yang terus menghangat di kalangan pemikir Islam. Qutb menjelaskan bahwa politik pemerintahan dalam Islam dibangun di atas asas yang bersumber dari hati nurani, lebih dari sekedar dibangun di atas asas syari'at. Ia dibangun atas asas bahwa Allah SWT. selalu hadir setiap saat di sisi para penguasa dan rakyat mengawasi segala sesuatunya. Namun demikian, tidak bisa juga dipahami bahwa sistem sosial Islam hanya dibangun atas asas yang bersumber dari hati nurani saja. Akan tetapi yang mesti dipahami adalah bahwa dalam Islam terdapat jaminan lain selain yang ditetapkan melalui syara'. Inilah yang membuatnya berbeda dengan sistem-sistem lain yang semata-mata didasarkan atas undang-undang belaka, tanpa dukungan jaminan yang keluar dari hati nurani dan perasaan.
\end{abstract}

Kata kunci: Politik Mesir, Ikhwanul Muslimin, Revolusi Mesir

\section{Pendahuluan}

Sayyid Qutb Ibrahim Husayn al-Syadzili, dilahirkan pada tanggal 9 Oktober 1906 di desa Musha. Desa Musha sendiri terletak di pantai Barat Sungai Nil, termasuk dalam wilayah Asyut yakni 235 mil sebelah selatan Kairo. Namun demikian, ada yang menyebutkan juga bahwa Sayyid Qutb dilahirkan di desa Qaha dan bahkan pada Bulan September 1906. ${ }^{1}$ ini berarti bahwa Sayyid Qutb dilahirkan pada setahun sesudah kewafatan Syaikh Muhammad Abduh.

${ }^{1}$ Yvone Y. Haddad menyebutkan bahwa Sayyid Qutb dilahirkan di desa Qaha pada bulan Oktober. Lihat Yvone Y. Haddad "Sayyid Qutb: Ideogue of Islamic Revival" dalam John L. Esposito (ed) Voice of Resurgent Islam (New York: Oxford University Press, 1983), h. 68. Senada dengan Haddad, Ahmad Sulaiman juga menyebutkan bahwa Sayyid Qutb lahir di Qaha dan justru pada Bulan September. Lihat al-Usymawi Ahmad Sulaiman, al-Syâhid Sayyid Qutb (Kairo: Dar al-Da'wat, 1969), h. 9 
Keluarga Sayyid Qutb merupakan keluarga ilmuan dan aktivis. Ayahnya yang bernama al-Haj Qutb Ibn Ibrahim merupakan seorang petani kaya dan terhormat yang menjabat sebagai komisaris Partai Nasional pimpinan Mustafa Kamil yang cukup dikenal di Asyut. Ayah Qutb dikenal memiliki konsistensi keilmuan yang karenanya ia sering berurusan dengan pemerintah. Pemikiran-pemikirannya yang kontroversial yang disampaikan lewat ceramah, khutbah dan berbagai kesempatan, sering berbenturan dengan kebijakan kerajaan yang dikendalikan oleh Inggris. Adapun ibu Sayyid Qutb, menurut Zainab al-Ghazali, berasal dari keluarga ilmuan mengingat ayah dari ibu Qutb merupakan alumnus dari Universitas al-Azhar yang dikenal warâ' dan dermawan. ${ }^{2}$

Sebagaimana yang diceritakan Barakat, Qutb (sebutan pendek Sayyid Qutb) memulai pendidikan formalnya pada usia 6 tahun dengan belajar di Sekolah Dasar Modern (madrasah) sebagai model pendidikan yang lain di samping Sekolah Qur'ani Tradisional $(k u t t a \hat{b})$. Adanya dua model pendidikan ini mengindikasikan kuatnya tarik-menarik antara faham tradisional dan moderat yang saat itu berkembang di Mesir. Namun demikian, Qutb tetap memperoleh pendidikan budaya Muslim Arab tradisional, hal mana telah mengakibatkan Qutb menghafal al-Qur'an dan pengetahuan Bahasa Arab pada umur 10 tahun, sebelum menamatkan pendidikan dasarnya di Musha. ${ }^{3}$

Pada tahun 1921 Qutb berangkat ke Kairo untuk melanjutkan sekolahnya di Madrasah Tsanawiyah. Di Kairo Qutb tinggal bersama pamannya, Ahmad Husain Usman yang saat itu telah menyelesaikan pendidikannya di al-Azhar dan bekerja sebagai guru dan penulis. Qutb berhasil menamatkan studinya tahun 1925 dan melanjutkan ke tingkat Mu'allimin di Kairo. Di Mu'allimin Qutb belajar selama 3 tahun dan mendapat ijasah 'Kafâ'at' (kelayakan mengajar). ${ }^{4}$ Belum puas sampai di situ, tahun 1928 Qutb kemudian

2 Zainab al-Ghazali, Perjuangan Wanita Ikhwanul Muslimin, terj. (Jakarta: Gema Insani Press, 1993), h. 144

3 Muhammad Tawfiq Barakat, Sayyid Qutb: Khulâshah Hayâtuh, Minhajuh fì al-Harakah, al-Naqd al-Muwajjah Ilaih (Mekah: Maktabah alMunarah, $\mathrm{tt})$, h. 9

${ }^{4}$ Shalah Abd. Al-Fattah al-Khiladi, Sayyid Qutb al-Syahid al-Hayy (Amman: Maktabat al-Aqsha, 1981), h. 88. Merupakan hasil wawancaranya dengan Muhammad Qutb. 
melanjutkan studinya ke Darul Ulum dimana terlebih dulu mengikuti perkuliahan persiapan selama 2 tahun. Darul Ulum sendiri di samping terkenal dengan pusat pergerakan mahasiswanya, juga terkenal dengan pendidikan agama dan sastra Arabnya. ${ }^{5}$

Barakat juga menambahkan bahwa selama menjadi mahasiswa di Darul Ulum, Qutb aktif dalam kegiatan mahasiswa dan sastra. Ceramahnya yang bertema al-Syấir fî al-Hayâh pada saat dia tingkat III, akhirnya diterbitkan dengan judul Muhimmah al-Syâir fi al-Hayâh. Dalam bidang sastra, Qutb sendiri menjadi pengagum serta banyak dipengaruhi oleh Thaha Husain, Ahmad al-Zayyat dan terutama Abbas Mahmud al-Aqqad, seorang modernis, wartawan, juru bicara Partai Wafd, serta pemimpin sekolah baru sastra modern terkenal "Diwân". Setelah empat tahun mempelajari sejarah, geografi, bahasa Inggris, ilmu sosial, pendidikan, ilmu pasti dan fisika, Qutb berhasil meraih gelar 'Lisance' (S1) dalam bidang sastra sekaligus diploma pendidikan. ${ }^{7}$

Menurut Muhammad Qutb, ${ }^{8}$ Setelah menyelesaikan pendidikannya di Darul Ulum, Qutb diangkat menjadi penilik pada Kementrian Pendidikan dan Pengajaran Mesir. Masa-masa itu merupakan masa dimana pengaruh pemikiran Abduh sedang berkembang. Murid-murid dan pengikut Abduh banyak menempati posisi-posisi penting di berbagai sektor. Sesudah menjadi penilik, Qutb beralih tugas menjadi sekretaris Thaha Husein dan Abbas Mahmud al-Aqqad dimana keduanya adalah murid Muhammad Abduh. Pergaulannya dengan Thaha Husein dan Abbas Mahmud al-'Aqqad semakin memperluas wawasan keilmuannya. Sebab, tidak lama sejak saat itu, tulisan-tulisan Qutb muncul dalam

5 Ahmad Salabi, Mausû'at al-Târîkh al-Islâmî wa al-Hadlârat alIslâmiyyat (Kairo: Maktabat al-Nahdhat al-Mishriyyah, 1972), h. 300

6 Muhammad Tawfiq Barakat, h. 10. Lihat juga Shahrough Akhavi, "Sayyid Qutb" dalam John L. Esposito (ed), The Oxford Encyclopedia of the Modern Islamic World, vol. III (New York: Oxford University Press, 1995), h. 400

7 Abd. Al-Salah al-Khalidi, Sayyid Qutb al-Syahid al-Hayy (Amman: Maktabat al-Aqsha, 1981), h. 89

${ }^{8}$ Muhammad Qutb, Sukhriyyât Shaghîrat (Beirut: Dar al-Lubnah, tt), h. 8

TAJDID Vol. XIV, No. 1, Januari-Juni 2015145 
berbagai majalah yang lazimnya memuat tulisan-tulisan para ahli seperti al-Risâlat dan al-Muqtathaf. ${ }^{9}$

Sebagaimana diketahui, Thaha Husein merupakan Murid Muhammad Abduh yang kemudian menjadi tokoh nasionalisme sekuler di Mesir, sebagaimana dua tokoh lainnya yakni Luthfi alSayyid dan Abdurraziq. Al-Khalidi menceritakan bahwa terdapat pengaruh al-'Aqqad yang besar pada diri Qutb dan tidak hanya itu, Qutb ternyata begitu tertarik kepada "Aqqad dan fanatik terhadapnya. Ketika Thaha Husein memberikan gelar 'Amîr alSyu'ârâ' (Panglima Para Penyair) kepada 'Aqqad, Qutb berkomentar bahwa gelar itu tidak tepat baginya, sebab menurut Qutb perbedaan 'Aqqad dengan para penyair Arab lainnya lebih besar dari perbedaan antara orang-orang pasar dengan para raja. Qutb bahkan mengakui akan kefanatikannya pada 'Aqqad dimana dia pernah berkata, "Saya akui bahwa saya adalah orang yang memiliki ghirah yang sangat besar dan sangat fanatik kepada tokoh ini. $^{10}$

\section{Kondisi Sosial dan Tradisi Intelektual}

Terdapat satu peristiwa penting untuk menandai profil Sayyid Qutb, satu peristiwa yang bukan hanya menunjukkan kecintaan Qutb kepada 'Aqqad, akan tetapi sekaligus menggambarkan corak pemikiran Qutb. Dalam peristiwa itu al-'Aqqad berpolemik dengan Mushtafa Shadiq al-Rafi'i tentang kemu'jizatan al-Qur'an. Qutb berpihak pada al-'Aqqad yang tidak menyetujui pendapat al-Rafi'i yang mengakui adanya ketinggian sastra al-Qur'an, padahal Qutb dikenal sebagai alumnus Darul Ulum yang terkenal karena ilmuilmu agamanya itu. Mahmud Muhammad Syakir mencela Qutb seraya mengatakan bahwa kritik Qutb terhadap al-Rafi'i berarti menjauhi agama, ketakwaan dan 'murû'at'. ${ }^{11}$ Tentang hal ini, Qutb sendiri berpandangan bahwa sastra adalah ungkapan jiwa, perasaan dan aspirasi manusia yang sama sekali tidak ada hubungannya dengan agama. ${ }^{12}$

Dari pergaulan Qutb dengan murid-murid Muhammad Abduh, memang sangat memungkinkan kalau Qutb akan banyak

\footnotetext{
${ }^{9}$ Fadhlullah Mahdi, Ma'a Sayyid Qutb fi Fikri al-Siyasi wa al-Dini,
}

(Kairo: Dar al-Da'wat, 1978), h. 25

${ }^{10}$ Al-Khalidi, Sayyid Qutb, h. 102

${ }^{11}$ al-Risalat, no 241, h. 255-256

12 al-Risalat, no. 263 , h. $1179-1180$ 
terpengaruh oleh pemikiran-pemikiran rasional yang berkecenderungan ke Barat. Di samping itu, pandangan Qutb yang memisahkan sastra dari Qur'an sekilas tampak bernada sekuler. Pada fase ini, profil Sayyid Qutb tampak seperti profil para pembaharu Islam yang berkecenderungan Barat, yang tidak sepi dari gaya berpikir sekularis.

Namun demikian, kondisi ini ternyata tidak berlangsung lama, mengingat pemikiran dan beberapa tindakan Qutb bertolak belakang dari itu semua. Peristiwa kematian ibunda Qutb pada tahun 1940 disebut-sebut telah mengakibatkan terjadinya perubahan besar pada diri Qutb melebihi dari pada saat ayahnya meninggal dunia. ${ }^{13}$ Tanggung jawab Qutb untuk mengasuh adikadiknya untuk menggantikan kedudukan ayah dan ibunya, disebutsebut sebagai salah satu faktor yang telah membawa pengaruh tersendiri di dalam hidupnya. Sayyid Qutb seolah menemukan kegairahannya kembali untuk mendalami al-Qur'an selain telah menghafalnya.

Adnan Musallam pernah menggambarkan bahwa terdapat beberapa faktor yang mendorong Sayyid Qutb mendalami alQur'an, yakni faktor internal dan eksternal. Meninggalnya ibunda Qutb, kesehatannya yang terganggu dan keterasingannya dari status quo dan budaya Barat merupakan serentetan faktor internal. Sementara faktor eksternalnya adalah keinginan mencari jawaban terhadap al-Qur'an untuk menanggulangi penyakit yang tengah melanda masyarakat. ${ }^{14}$ Akibat pemahaman dan pendalamannya terhadap al-Qur'an ternyata telah mengubah corak pemikirannya, dari yang cenderung sekuler menuju kepada pemikiran yang amat concern terhadap Islam. Fenomena ini semakin jelas ketika pada tahun 1945, Qutb berhasil mempersembahkan dua buah karyanya yakni al-Taswîr al-Fannî fì al-Qur'ân untuk mengenang ibunya, dan Masyâhid al-Qiyâmah fì al-Qur'ân untuk mengingat ayahnya.

Di dalam kedua karyanya tersebut Qutb menyatakan bahwa alQur'an memiliki bahasa dan susunan yang sangat indah yang

${ }^{13}$ Sayyid Qutb, et. al., al-Atyâf al-Arba'ah (Beirut: Dar al-Lubnah, 1967), h. 165

14 Adnan A. Musallam, "Sayyid Qutb and Social Justice", dalam Journal of Islamic Studies (Januari, 1993), vol. 4, h. 56 
membuktikan bahwa al-Qur'an bukan ciptaan manusia. ${ }^{15}$ Bahkan di dalam al-'Adâlat al-Ijtimâ'iyyat fì al-Islâm yang terbit pada tahun 1948, Qutb menegaskan bahwa keadilan yang menjadi citacita umat manusia tidak akan mungkin terwujud kecuali harus dengan Islam. Itulah sebabnya maka kitapun harus memiliki sastra yang memancar dari pandangan Islam. ${ }^{16}$ Dengan demikian tampak di sini kalau Qutb lebih concern terhadap Islam, dimana segala hal baginya harus memiliki landasannya pada al-Qur'an.

Bukan hanya melalui tulisan-tulisannya tersebut, kita melihat corak dan profil Qutb yang berubah dari sebelumnya. Hal yang sangat nyata adalah sikapnya yang mulai melepaskan diri dari al'Aqqad. Secara jujur dia menyatakan bahwa pandangannya yang seperti itu diperolehnya melalui penghayatan dan kajiannya terhadap al-Qur'an. ${ }^{17}$ Kini Qutb tidak hanya melepaskan diri dari pengaruh-pengaruh Barat, melainkan secara gencar melancarkan kritik terhadapnya. Qutb pernah menyatakan bahwa peradaban Barat adalah peradaban materialistik yang kosong dari nilai-nilai spiritual. Ungkapan ini disampaikannya ketika pada tahun 1949 Qutb berkunjung ke Amerika sebagai utusan kebudayaan untuk mempelajari sistem pendidikan di sana. Qutb tinggal di Amerika selama dua setengah tahun dan telah hilir mudik antara Washington dan California. Setelah melakukan pengamatan langsung akan budaya Amerika tersebut, Qutb berkesimpulan bahwa sekalipun Barat berhasil meraih kemajuan pesat dalam sains dan teknologi, namun sebenarnya peradaban ini rapuh karena kosong dari nilainilai spiritual. ${ }^{18}$

Bagi Qutb, Islam adalah pedoman hidup yang diciptakan Allah untuk manusia. Sepanjang manusia mengalami perkembangan dan perubahan, maka Islam pasti sesuai untuk segala waktu dan tempat. ${ }^{19}$ Penolakan terhadap Barat pada sisi lain dapat ditemukan pada ketidaksetujuannya untuk memadankan antara musyawarah dengan demokrasi. Demokrasi sebagai suatu sistem mempunyai

${ }^{15}$ Sayyid Qutb, al-Taswîr al-Fannî fì al-Qur'ân, h. 5, 7 dan lihat pula Sayyid Qutb, Masyâhid al-Qiyâmah fî al-Qur'ân (Beirut: Dar al-Syuruq, 1976), h. 5, 8)

${ }^{16}$ Sayyid Qutb, al- 'Adalah al-Ijtima'iyyah fi al-Islam (Dar al-Khatib al'Arabi, tt), cet. 8, h. 278

${ }^{17}$ Sayyid Qutb, al-Taswîr, h. 10

${ }^{18}$ Sayyid Qutb, al- 'Adâlat, h. 284

${ }^{19}$ Sayyid Qutb, Fi Zhilâl, juz VI, h. 842 
filsafat dan sumber tersendiri yang berbeda dari musyawarah. Kaum Muslim menurut Qutb tidak perlu mengambil sistem dari luar Islam, sebab Islam --- sebagai pedoman hidup yang diciptakan Tuhan untuk manusia --- pasti cocok untuk semua waktu dan tempat. $^{20}$

Dengan profil seperti ini, Montgomery Watt dalam bukunya Islamic Fundamentalism and Modernity pernah menyebut sikap dan pemikiran Qutb sebagai salah satu ciri kaum fundamentalis. Menurut Watt, karena adanya anggapan bahwa Islam self sufficiency (cukup diri) dan merupakan agama terakhir bagi umat manusia, maka ia tidak membutuhkan perubahan mendasar apapun. Karena itu, maka sementara kaum Muslimin menolak pembaharuan yang datang dari luar, dan ini merupakan salah satu ciri tradisionalis-fundamentalis. ${ }^{21}$ Watt sepertinya melihat adanya indikasi perasaan self sufficiency pada Qutb, ketika Qutb melihat adanya kekeroposan nilai pada masyarakat Barat, serta mengagungkan Islam sebagai ajaran yang sempurna.

Tahun 1949 barangkali merupakan tahun awal-awal bagi terjadinya perubahan, atau lebih tepatnya perkembangan, pada diri Qutb. Sebelumnya, keberadaannya di Amerika memang belum memberikan andil secara praktis dalam kehidupan politik dan pergerakan Islam di negerinya. Satu peristiwa yang kemudian menjadikan profil Qutb tidak hanya sekedar ilmuan dan penulis, melainkan sebagai seorang aktifis dan pejuang Islam yang lebih bergairah dan semakin gigih, adalah kematian Hasan al-Banna. Kematian al-Banna --- sebagai tokoh Ikhwanul Muslimin --- pada Februari 1949 yang disambut luapan suka cita oleh masyarakat Amerika. Surat kabar dan semua media massa lainnya serta di tempat-tempat pertemuan, kesemuanya menyatakan kegembiraan dan saling mengucapkan selamat atas terbebasnya mereka dari ancaman seorang laki-laki dari Timur. ${ }^{22}$

Al-Khalidi menyebutkan bahwa perkenalan Qutb dengan John Houritz Dunn --- seorang intelijen Inggris yang menetap di Amerika yang kemudian masuk agama Islam --- semakin menyadarkan Qutb akan perjuangan Hasan al-Banna dan Ikhwanul

${ }^{20}$ Sayyid Qutb, Khashâish, h. 40

21 W. Montgomery Watt, Islamic Fundamentalism and Modernity (London: Routledge, 1988), h. 4

${ }^{22}$ Majalah Al-Mujtama', no. 115, 29 Agustus 1972, h. 16 
Muslimin. Menurut al-Khalidi, Dunn pernah menyodorkan berbagai dokumen tentang rencana-rencana Inggris dan Amerika di Mesir, khususnya sikap mereka terhadap Ikhwanul Muslimin sejak organisasi ini didirikan tahun 1928 hingga terbunuhya Hasan alBanna tahun 1949. Dokumen Dunn itu juga menyebutkan bahwa manakala Inggris angkat kaki dari Mesir, maka Amerikalah yang akan menggantikan kedudukan Inggris. ${ }^{23}$

Sejak saat itulah terjadi perubahan pada diri Qutb untuk lebih mengabdikan sepenuh hidupnya untuk perjuangan Islam, khususnya melalui organisasi Ikhwanul Muslimin. Hal ini pernah diakui oleh Qutb sendiri, sebagaimana dikutip Abdullah 'Azzam, Qutb menyatakan;

"Kini terungkaplah kebenaran itu, dan saya yakin bahwa organisasi ini (al-Ikhwanul Muslimin) berada di pihak yang benar, dan pasti tidak ada ampunan untuk saya di sisi Allah manakala saya tidak mengikutinya. Lihatlah Amerika ini, ia berusaha menindas Hasan al-Banna dan Inggris pun mengerahkan seluruh personil dan media propagandanya, bahkan di Amerika Serikat sekalipun, untuk memerangi Ikhwanul Muslimin. Karena itu saya tegaskan pada diri saya bahwa saya bergabung dengan al-Ikhwanul Muslimin saat saya belum lagi keluar dari rumah intelijen Inggris ini". 24

Pada tahun 1950, Qutb meninggalkan Amerika dan tiba di Mesir. Setibanya di Mesir, Qutb banyak mencari informasi mengenai kepribadian Hasan al-Banna. Setelah mengetahui kalau Hasan al-Banna dimusuhi dan dibunuh, maka lagi-lagi Qutb semakin kagum kepada al-Banna sembari bertekad, "Saya putuskan untuk memikul amanat sesudahnya, dan melanjutkan perjuangan dengan cara seperti yang ditempuhnya sampai dia menghadap Allah. ${ }^{25}$ Dari sinilah kegairahan dan kekaguman Qutb terhadap alBanna itu bermula.

Qutb sendiri secara terang-terangan menyatakan bahwa terdapat dua hal yang membuatnya kagum terhadap al-Banna sehingga memiliki tekad untuk meneruskan perjuangan al-Banna. Pertama, kemampuan al-Banna dalam membentuk keseimbangan

${ }^{23}$ Al-Khalidi, Sayyid Qutb, h. 128

${ }^{24}$ Abdullah 'Azzam, "al-Syâhid Sayyid Qutb”, dalam al-Khalidi, Sayyid Qutb, h. 136

${ }^{25}$ Al-Mujtama', no. 115 , h. 11 
antara aspek keilmuan, spiritual dan perjuangan pada diri anggotaanggota ikhwan serta sikap tengahnya dalam menghadapi berbagai aliran Islam, semisal aliran dalam tasawuf, salafiyah dan madzhabmadzhab fiqh. Kedua, kemampuan al-Banna dalam mengorganisasi massa. Menurut Qutb, Ikhwanul Muslimin adalah organisasi pertama di dunia yang sanggup melakukan amal sosial yang menyeluruh di antara organisasi-organisasi sejenisnya pada saat itu. $^{26}$ Di sini jelas bahwa kekaguman Qutb terhadap al-Banna meliputi aspek keilmuan dan kiprahnya dalam membawa Ikhwan al-Muslimun sebagai organisasi Islam termasyhur.

Sementara itu, tahun 1951 merupakan tahun dimana Qutb mulai mempersembahkan pengabdiannya kepada Ikhwanul Muslimin, dalam rangka perjuangan Islam. Begitu bergairahnya Qutb sehingga ia menyebut tahun ini sebagai tahun 'kelahiran'nya. "Saya lahir tahun 1951", katanya. Hal ini karena waktu 45 tahun sebelumnya ia anggap tidak pernah ada. ${ }^{27}$ Sejak itu, di samping meneruskan aktivitas rutinnya yakni menulis, Qutb memberikan ceramah dan kuliah, menghadiri pertemuan dan diskusi. Tulisan dan ceramahnya banyak memikat hati pembaca dan pendengarnya. Bukan hanya di markas Ikhwanul Muslimin yang tidak pernah sepi dari pengunjung baik pemuda, mahasiswa maupun umum untuk mendengarkan ceramahnya. Bahkan rumahnya di al-Halwan menjadi tempat pertemuan para pemimpin pergerakan semisal Gamal Abdul Nasser, hingga beberapa hari menjelang revolusi 1952 .

Revolusi Mesir tahun 1952 ternyata telah menempatkan Qutb pada posisi yang terhormat, di samping Muhammad Najib, Gamal Abdul Nasser dan lainnya. Pada Agustus 1952 atau beberapa hari setelah revolusi para pemimpin revolusi meminta Qutb menyampaikan pidatonya di depan para prajurit di al-Zamalik. Diceritakan bahwa pemimpin tertinggi revolusi yakni Muhammad Najib akan menyambut sendiri kedatangan Qutb. Karena tidak bisa hadir, Najib mengirimkan sambutan tertulis lewat Anwar sadat, dimana isinya antara lain memuji diri Qutb. Najib mengatakan, "Sayyid Qutb adalah Pencetus Revolusi (Râ'id al-Tsaurat), Pemimpin dari Para Pemimpinnya (Qa'id Qadâtih) dan Ketua dari

26 Sayyid Qutb, "Hasan al-Bannâ wa "Abqariyyât al-Binâ", dalam Dirâsat Islâmiyyat (Beirut: Dar al-Syuruq, 1982), h. 225-230

${ }^{27}$ Abdullah 'Azzam, "al-Syâhid Sayyid Qutb”, h. 46 
Ketua-ketuanya (Ra'is Ru'asâih). Pidato Qutb disambut dengan antusias yang tinggi oleh pendengarnya dimana di dalamnya ia menyatakan kalau, "Sekarang revolusi betul-betul telah dimulai. Akan tetapi kita tidak boleh menyanjung-nyanjungnya, sebab dia belum memberikan sesuatu yang berarti. Diturunkannya Raja Fu'ad bukanlah tujuan revolusi ini, akan tetapi tujuannya adalah mengembalikan negeri ini kepada Islam" ${ }^{28}$. Bisa dipastikan bahwa selama kepemimpinan Raja Fu'ad, Mesir dipandang sebagai negara Muslim yang kurang islami.

Pasca revolusi, Qutb pernah menduduki posisi sebagai Penasehat Dewan Pimpinan Revolusi untuk urusan kebudayaan dan dalam negeri. Jabatan ini hanya dipangkunya selama beberapa bulan saja. Terdapat beberapa jabatan strategis yang pernah ditawarkan kepada Qutb namun ia tolak, yakni jabatan Menteri Pendidikan Mesir dan Direktur Umum Penerangan. Akhirnya Qutb setuju menerima jabatan Sekretaris Umum Liga Pembebasan (Hai'at al-Tahrîr). Jabatan ini cukup strategis karena menyangkut penentuan kebijaksanaan politik Mesir. Jabatan ini dipegangnya selama beberapa bulan. ${ }^{29}$

Namun demikian, sudah menjadi sifat kehidupan yang tidak selamanya berjalan mulus. Seiring dengan dimulainya pembangunan Mesir pasca revolusi, mulailah kelihatan adanya perbedaan visi dan misi serta arah kebijakan negara, terutama antara Sayyid Qutb dengan Gamal Abdul Nasser. Perbedaan yang cukup mendasar adalah bahwa Sayyid Qutb menginginkan agar Mesir menjadi negara yang berlandaskan pada syari'at Islam, sedangkan Nasser --- yang saat itu telah menggantikan Najib menjadi Presiden --- cenderung bervisikan sekular. Peristiwa awal yang meregangkan hubungan kedua tokoh ini segera terlihat ketika Nasser memaksa Qutb untuk meletakkan jabatannya untuk kemudian jabatannya dirangkap oleh Nasser sendiri. ${ }^{30}$ Persoalan ini menjadi rumit karena ia telah melibatkan keyakinan keagamaan. Di sini terlihat bahwa Qutb yang merupakan tokoh Islam yang komit

${ }^{28}$ Kesaksian Mahmud al-'Azb (perwira militer yang bergabung dalam al-Ikhwan al-Muslimin. Dimuat dalam Kalimât al-Haqq, dikutip dari Abdullah 'Azzam, "al-Syâhid Sayyid Qutb", h. 140

${ }^{29}$ Ibid., h. 29

${ }^{30}$ Ibid 
atas Islam, berhadapan dengan Nasser yang tidak terlalu komit terhadap perealisasian Islam secara utuh.

Semua itu berakibat pada hubungan Qutb serta Ikhwanul Musliminnya dengan Dewan Revolusi yang semakin tidak harmonis. Ikhwanul Muslimin mulai mengontrol Dewan Revolusi, dan tidak jarang terjadi penolakan kebijakan Dewan Revolusi yang dilakukan oleh Ikhwanul Muslimin. Satu peristiwa besar telah memberi andil yang besar bagi hancurnya Ikhwanul Muslimin di Mesir serta penghukuman tokoh-tokohnya. Adalah Muhammad Abdul Latif salah seorang anggota Ikhwanul Muslimin gagal melakukan pembunuhan terhadap Nasser tanggal 28 Oktober 1954. Segera setelah kejadian ini enam orang anggota Ikhwan diadili dan dihukum gantung. Bahkan sumber mereka menyatakan bahwa lebih dari tiga ratus anggota mereka dihukum kerja paksa untuk jangka panjang, sebelas ribu menerima hukuman. ${ }^{31}$ Sayyid Qutb juga terkena imbasnya dimana pada masa-masa ini terjerat hukuman 15 tahun penjara. Karena memperoleh grasi, maka hukuman Qutb diperingan menjadi 10 tahun.

Ketidakharmonisan terus berlangsung antara Ikhwanul Muslimin dan pemerintah atau Dewan revolusi. Kembali satu peristiwa besar terjadi, dimana kali ini hukuman berat yakni hukuman mati menimpa diri Sayyid Qutb serta pembubaran organisasi Ikhwanul Muslimin. Bermula dari berkunjungnya Nasser ke Moskow pada tahun 1965, di sana Nasser membeberkan adanya kudeta terhadap dirinya yang dilakukan oleh Ikhwanul Muslimin di bawah pimpinan Sayyid Qutb. Kurang jelas apakah kudeta itu benar-benar ada atau tidak. Namun demikian, yang jelas Pengadilan Tinggi menjatuhkan hukuman mati kepada Sayyid Qutb. Akhirnya menjelang fajar tanggal 29 Agustus 1966 atau bertepatan dengan tanggal 13 Jumadil Ula 1386 H, Sayyid Qutb menjalani ekskusi. ${ }^{33}$ Ekskusi atas Sayyid Qutb menuai kritik dari berbagai penjuu dunia Islam. Namun demikian, sepertinya hal itu tidak membawa perubahan pada sikap Nasser.

Setelah Sayyid Qutb diekskusi, satu peristiwa besar seolah turut mengiringi kepergiannya. Kali ini organisasi Ikhwanul Muslimun dibubarkan. Anggota-anggotanya banyak yang

\footnotetext{
${ }^{31}$ Al-Husaini, al-Ikhwân al-Muslimûn, h. 183

${ }^{32}$ Fadlullah, Ma'a Sayyid Qutb, h. 29

${ }^{33}$ Al-Khalidi, Sayyid Qutb, h. 156
} 
ditangkap dan diadili serta dijebloskan ke penjara. Seiring dengan banyaknya anggota Ikhwan yang dijebloskan ke penjara, maka Mesir kehilangan banyak guru, pemimpin agama, teknisi dan tenaga ahli lainnya. Bukan itu sebenarnya yang menjadi tujuan revolusi, namun demikian, usaha pembunuhan terhadap Nasser disebut-sebut menjadi penyebab bagi Nasser untuk menggunakan tangan besinya. ${ }^{34}$ Sudah jatuh kemudian ketiban tangga, itulah barangkali pepatah yang pas buat Ikhwan al-Muslimun kala itu. Tokoh-tokoh besar dari oranisasi ini harus menjalani ekskusi dan dipenjarakan, dimana kemudian diikuti juga oleh dibubarkannya organisasi Ikhwan al-Muslimun.

\section{Pemikiran Politik Sayyid Qutb}

Sebelum membahas pemikiran kenegaraan Sayyid Qutb, satu hal yang kiranya perlu disampaikan adalah pandangan Qutb secara umum mengenai konsepsi masyarakat. Bagi Qutb, secara umum masyarakat dibagi ke dalam dua bagian yakni 'Masyarakat Islam' dan 'Masyarakat Jahiliyah'. Masyarakat Islam adalah masyarakat yang melaksanakan Islam, baik dalam akidah dan ibadah, dalam syariat dan nizam, maupun dalam akhlak dan perilaku. Sebaliknya, masyarakat jahiliyah adalah masyarakat yang tidak melaksanakan Islam. Masyarakat ini tidak dikendalikan oleh akidah dan konsepsi Islam, juga tidak oleh nilai, mizan, syariat, akhlak dan perilaku Islam. ${ }^{35}$ Pembagian masyarakat ke dalam dua jenis ini terasa agak ketat, hitam putih dan terkesan ekstrem. Dengan demikian, kriteria masyarakat untuk disebut Islam atau jahil adalah tergantung dari dijalankan tidaknya ajaran Islam.

Bagi Qutb, masyarakat Islam bukan sekedar masyarakat yang beranggotakan orang-orang Islam, tetapi sementara syariat Islam tidak ditegakkan, meskipun mereka shalat, berpuasa dan haji. Masyarakat Islam bukan masyarakat yang melahirkan suatu jenis Islam khusus untuk dirinya sendiri, di luar ketetapan Allah Yang Maha Suci dan yang telah dijelaskan oleh Rasulullah SAW. Masyarakat jahili dapat mengambil berbagai model, semuanya jahili. Boleh jadi ia berbentuk suatu masyarakat yang tidak percaya kepada adanya Allah dan memberikan penafsiran dialektis materialistis kepada sejarah serta melaksanakan sistem yang

${ }^{34}$ Al-Dhanawi, al-Thâriq ilâ al-Hukm al-Islâmî, h. 223

35 Sayyid Qutb, Fi Dzilal al-Qur'an (Makkah: Dar al-'Ilmi Li' Thiba'ah, 1986), h. 64 
dinamakan "sosialisme ilmiyah" (al-Isytirôkiyyah al-'Ilmiyah). Menurut Qutb masyarakat ini bisa berbentuk suatu masyarakat yang tidak mengingkari eksistensi Allah, tetapi memisahkan kekuasaan Allah, dimana kekuasaan langit mereka serahkan kepada Allah dan kekuasaan (kerajaan) bumi bukan lagi urusan Allah. ${ }^{36}$ Penjelasan ini mengindikasikan bahwa ukuran sebuah masyarakat untuk dikatakan Islam adalah bukan ukuran kuantitatif (banyaknya kaum Muslim), tetapi kualitatif yakni sejauhmana ajaran Islam bisa dijalankan secara utuh.

Seterusnya Qutb menambahkan bahwa di dalam sistem kehidupan jahili syariat Islam tidak dilaksanakan. Nilai-nilai yang ditetapkan Allah sebagai nilai yang tetap dalam masyarakat jahili tidak dianggap berkuasa dalam kehidupan manusia. Mereka memperbolehkan manusia menyembah Allah di masjid-masjid, gereja, sinagog dan klenteng-klenteng, tetapi tidak dibolehkan manusia menuntut berhukum kepada syariat Allah dalam kehidupannya. Dengan demikian ia mengingkari dan mengabaikan uluhiyyah Allah di atas bumi, padahal Allah telah berfirman: "Dialah yang menjadi Ilah di langit dan di bumi" (al-Zukhruf, 84). Ini artinya masyarakat tersebut tidak lagi berada dalam dinullah. Dengan demikian masyarakat itu adalah masyarakat jahili, sekalipun mereka mengakui wujudullah yang Maha Suci dan membiarkan orang-orang melakukan upacara ibadah kepada Allah dalam sinagog, gereja dan masjid. ${ }^{37}$ Penjelasan ini sepertinya lebih tepat disebut peringatan dari Qutb dimana kaum Muslim jangan terkecoh oleh penampilan luar sebuah masyarakat. Meskipun kelihatannya sebuah masyarakat itu damai, penuh toleransi dan sebagainya, namun jika hukum Allah tidak ditegakkan di dalamnya, itupun bagi Qutb termasuk masyarakat jahili.

Menurut Qutb, jika kekuasaan tertinggi dalam masyarakat hanya milik Allah saja, terlambang dalam tegaknya syariat ilahi, maka ini adalah satu-satunya bentuk dimana manusia dapat menjadi bebas secara sempurna dan dengan sebenar-benarnya dari penghambaan manusia. Inilah yang merupakan "peradaban manusia" yang sesungguhnya, karena peradaban manusia menghendaki adanya suatu fondasi pokok yang membebaskan manusia yang sesungguhnya dan sempurna. Fondasi untuk

\footnotetext{
${ }^{36}$ Ibid., h. 65

${ }^{37}$ Ibid
} 
meninggikan martabat yang mutlak bagi setiap individu dalam masyarakat. ${ }^{38}$

Di samping itu jika akidah yang dijadikan tali penguat dalam suatu masyarakat, demikian juga konsepsi, fitrah Islam, manhajul hayah, yang kesemuanya bersumber dari Allah SWT. dimana terlambang kedaulatan manusia tertinggi dan bukan bersumber pada tuhan-tuhan bumi yang melambangkan perbudakan manusia atas manusia, maka perhimpunan seperti ini menurut Qutb telah melambangkan karakteristik tertinggi yang terdapat dalam "manusia", yaitu ciri-ciri khas kejiwaan dan pemikiran. Namun sebaliknya, jika yang menjadi alat pengikat dari masyarakat itu adalah ras, warna kulit, bangsa atau tanah air, atau hubunganhubungan lain yang sejenis dengan itu, maka hal tersebut tidak mencerminkan ciri khas manusia yang tertinggi. ${ }^{39}$ Keterangan ini menunjukkan bahwa masyarakat Islam, dimana di dalamnya dilaksanakan ajaran Islam sebenarnya akan mendatangkan dampak positif berupa pembebasan manusia dari penghambaan akan sesama manusia. Jika ini bisa terjadi, maka martabat manusia benar-benar akan terjunjung tinggi.

Pandangan-pandangan Qutb mengenai kekuasaan sangat diwarnai oleh corak pemikiran keagamaannya yang kental dimana agama harus menjadi nafas bagi kekuasaan atau dengan kata lain, kekuasaan harus dijalankan di atas landasan agama dan di bawah undang-undang Tuhan. Menurut Qutb, kekuasaan yang mengatur hidup manusia haruslah kekuasaan yang mengatur adanya manusia itu. Manusia tidak boleh menyeleweng dan menciptakan sistem sendiri, kekuasaan sendiri, kebijaksanaan sendiri dan kebijaksanaan lain dari sistem, kekuasaan dan kebijaksaan Tuhan yang telah mengatur seluruh alam semesta. Tuhan yang bahkan telah mengatur adanya manusia itu sendiri dalam kehidupan mereka yang di luar kehendak mereka. Manusia tunduk kepada undangundang fitri yang telah dibuat Tuhan dalam penciptaan dan pertumbuhan mereka, dalam sehat-sakitnya mereka, dan dalam hidup-matinya mereka. Sebagaimana halnya manusia itu harus tunduk kepada undang-undang ini dalam persatuan sosial mereka dan kepada akibat yang mereka derita sebagai hasil kebebasan gerakan mereka sendiri. Mereka tidak sanggup merubah

\footnotetext{
${ }^{38}$ Ibid., h. 67

${ }^{39}$ Ibid., h. 68
} 
sunnatullah dalam hal peraturan alam semesta yang mengatur alam semesta ini dan tindak tanduknya. ${ }^{40}$ Qutb sepertinya memiliki militansi, komitmen dan konsentrasi yang tinggi dalam pemikiranpemikirannya dalam hal terealisasinya ajaran dan syari'ah Islam sebagai hukum dan undang-undang tertinggi di tengah-tengah masyarakat.

Dengan melandasi pada pemikirannya tersebut, maka menurut Qutb manusia hendaknya bersegera ke dalam Islam dalam segi kehidupan mereka yang iradi (dimana mereka memiliki kebebasan untuk memilih). Mereka jadikan syari'at Allah yang menjadi penguasa tunggal dari seluruh persoalan kehidupan. Dengan begitu kehidupan mereka yang fitri menjadi terjalin rapi dengan segi kehidupan mereka yang iradi. Dengan begitu terjalin rapi pulalah kedua segi adanya manusia ini dengan adanya alam semesta. (Untuk memperdalam persoalan ini lihat buku Prinsip-prinsip Islam karya Maududi). Tetapi paham jahiliyah yang berdasarkan berkuasanya manusia atas manusia, dan dengan begitu telah menyeleweng dari wujud adanya alam semesta dan bertentangan dari kehidupan manusia, maka faham jahiliyah seperti inilah yang telah dihadapi oleh setiap Rasul yang menyeru kepada Islam, terhadap penyerahan diri kepada Tuhan saja. Faham ini pulalah yang telah dihadapi Rasulullah saw. ketika berdakwah. ${ }^{41}$

Seterusnya Qutb berpendapat bahwa prinsip teoritis yang menjadi dasar Islam sepanjang perputaran sejarah adalah prinsip syahadat "lâ ilâha illa Allâh". Artinya hanya Allah saja yang menjadi Tuhan, Rab, Pendukung kehidupan, Penguasa dan Pemerintah. Hal ini dipercayai dalam hati nurani, diperlihatkan dalam upacara ibadah dan dinyatakan dalam bentuk hukum dalam kehidupan sehari-hari. Hanya dalam bentuk seperti inilah syahadat "lâ ilâha illa Allâh" baru dapat dianggap benar-benar ada, dan dianggap ada secara syara'. Ia baru dapat dianggap ada dalam bentuk seperti ini dalam bentuk yang saling menyempurnakan, yang memberikan kepadanya suatu entity, suatu kepribadian yang sungguh-sungguh ada. Inilah yang dipakai sebagai kriteria, ukuran, dari ucapan seseorang yang berkata bahwa ia Islam atau tidak. ${ }^{42}$ 68

${ }^{40}$ Sayyid Qutb, Ma'alim fi al-Thariq (Jakarta: Media Dakwah, ), h. 67-

${ }^{41}$ Ibid., h. 68-69

${ }^{42}$ Ibid., h. 70 
Sebagai sesuatu yang prinsip dalam pemikiran Qutb khususnya dalam hal pembagian masyarakat ini adalah bahwa dalam masyarakat Islam hanya Allah jualah yang menjadi penguasa, pemerintah dan penentu hukum. Manusia hanya menjalankan undang-undang-Nya. Sedangkan dalam masyarakat jahiliyah, manusia menjadi penguasa bagi manusia lainnya atau dengan kata lain, manusia menghamba pada sesama manusia.

Bagi Qutb, arti mengakui prinsip ini dipandang dari segi teori adalah bahwa seluruh kehidupan manusia harus kembali kepada Allah. Manusia tidak berhak untuk memutuskan sendiri tentang hal apapun dalam kehidupannya. Manusia tidak dapat memutuskan sendiri, ia harus kembali kepada hukum Allah dan melihat hukum Allah dalam persoalan itu. Lalu diikutinya hukum Allah itu. Hukum Allah menurut Qutb harus diketahui manusia dari satu sumber saja yaitu sumber yang telah menyampaikan hukum ini kepada manusia, yaitu Rasulullah SAW. Inilah yang terkandung dalam bagian kedua dari hukum Islam pertama, yakni syahadat "Muhammadan Rasûlullâh". ${ }^{43}$ Tidak berlebihan manakala dikatakan bahwa serentetan pemikiran-pemikiran Qutb di atas merupakan paradigma politik Islam yang orisinil tentang bagaimana sebuah negara dijalankan di atas landasan Islam. Uraian-uraian Qutb memang mengarah pada definisi, format dan praktek sebuah negara Islam.

Sayyid Qutb berpendapat bahwa menurut ajaran Islam, kekuasaan menjamin kemantapan hubungan penguasa dan rakyat yang dipimpinnya atas dasar perdamaian, keadilan dan ketertiban sebagai landasan yang kokoh bagi tegaknya perdamaian. Penguasa mencapai kedudukannya harus melalui persetujuan rakyat dalam pemilihan bebas dan ia akan tetap bertahan pada kedudukannya hanya jika memenuhi satu syarat, yaitu taat kepada Allah dan melaksanakan syari'at-Nya. Dengan demikian maka menurut Islam, kekuasaan haruslah didasarkan pada kerelaan dan pilihan rakyat, musyawarah dan persetujuan rakyat yang dinyatakan melalui wakil-wakilnya. Kekuasaan itu harus dilaksanakan sesuai dengan ketentuan-ketentuan yang telah ditetapkan Allah SWT, kekuasaan yang dapat menciptakan kepercayaan dan ketenangan di kalangan rakyat dan dapat memberikan perasaan lega dan tenteram dalam hati semua orang. Dalam keadaan seperti itu tidak da alasan

\section{${ }^{43}$ Ibid., h. 71}


bagi siapapun untuk merasa jemu, pengab atau berpikir hendak menentang kekuasaan, selama kekuasaan itu menjalankan fungsinya sesuai dengan cara-cara dan batas-batas yang telah disyariatkan oleh Islam. ${ }^{44}$

Di sisi lain Sayyid Qutb juga memberikan batas-batas kekuasaan. Bagi Qutb, batas-batas kekuasaan itu adalah melaksanakan hukum dan perundang-perundangan yang telah disyari'atkan Allah SWT. bagi seluruh hamba-Nya yang tujuannya tidak lebih mengutamakan kepentingan seseorang daripada orang lain, tidak mengutamakan kepentingan kelas yang satu dan mengabaikan kepentingan kelas yang lain, tidak mengutamakan kepentingan kelompok yang satu dan meremehkan kepentingan kelompok yang lain dan tidak mengistimewakan orang-orang yang berkuasa lebih daripada orang yang berada di bawah kekuasaannya. Semua adalah hamba Allah, semua hukum dan perundang-undangan asalnya dari Allah dan semua manusia di hadapan Allah adalah sama. ${ }^{45}$ Dengan ketaatan yang semata-mata kepada Allah, Qutb tampaknya ingin menunjukkan bahwa di dalam Islam, semua manusia adalah sama derajatnya di hadapan Allah, baik penguasa maupun rakyat, perbedaan hanya pada aspek ketaatannya pada Allah SWT.

Ketaatan rakyat kepada penguasa sepenuhnya tergantung pada pelaksanaan hukum dan perundang-undangan yang disyariatkan Allah. Apabila penguasa menyelewengkan pelaksanaannya maka gugurlah wajib taat kepadanya. Mengenai hal itu Rasulullah SAW. telah bersabda: "Taatilah, walaupun yang diangkat sebagai penguasa kalian itu seorang budak habasyah (budak berasal dari Ethiopia) yang kepalanya mirip sebuah kismis, selama ia menjalankan kekuasaannya berdasarkan Kitabullah" (Hadis shahih diketengahkan oleh Bukhari). Jadi, batas ketaatan rakyat kepada penguasa hanya ditentukan oleh satu hal yakni selama penguasa menjalankan ketetapan-ketetapan sesuai dengan makna yang termaktub dalam Kitabullah. ${ }^{46}$ Qutb kiranya telah meletakkan dasar-dasar demokrasi ala Islam. Penguasa bagi Qutb hanyalah sarana bagi lebih lancarnya upaya realisasi ajaran Tuhan. Penguasa

${ }^{44}$ Sayyid Qutb, Al-Salam al- 'Alami wa al-Islam (Beirut: Dar al-Syuruq, 1983), h. 94

${ }^{45}$ Ibid., h. 94-95

${ }^{46}$ Ibid., h. 95 
sama dengan rakyat, oleh karenanya baik penguasa maupun rakyat harus meletakkan ketaatan kepada Allah. Maka sebagai hasil dari paradigma ini adalah suatu paradigma demokrasi yang berbeda dari konsep demokrasi Barat, dimana bagi Qutb, rakyat dibolehkan tidak mentaati penguasa yang telah menyeleweng dari hukum Tuhan.

Maka sebagai rentetan dari jalan pikirannya tersebut, Qutb menguatkannya dengan beberapa ayat al-Qur'an antara lain; "Barangsiapa yang menetapkan keputusan hukum tidak menurut apa yang telah diturunkan Allah, mereka itu adalah orang-orang kafir" (Qs. Al-Maidah, 44), "Tidakkah engkau (Muhammad) memperhatikan mereka yang mengaku dirinya telah beriman kepada apa yang telah diturunkan Allah kepadamu dan kepada apa yang telah diturunkan Allah sebelum engkau? Mereka itulah yang suka bertahkim (mencari dan menerima keputusan hukum) kepada taghut, padahal mereka telah diperintah supaya mengingkarinya. Setan memang hendak menyesatkan mereka sejauh-jauhnya" (al-Nisa, 60), "Maka demi Tuhanmu, (pada hakekatnya) mereka itu tidak beriman sebelum mereka bertahkim kepadamu mengenai perkara-perkara yang mereka perselisihkan, kemudian mereka di dalam hati tidak merasakan suatu keberatan terhadap keputusan yang engkau tetapkan, dan mereka menerimanya dengan sepenuh hati" (al-Nisa, 65). ${ }^{47}$

Di samping ayat-ayat tersebut, untuk menegaskan batas-batas kekuasaan penguasa, Qutb juga mengambil kisah pengangkatan Abu Bakar sebagai khalifah. Sebagaimana yang dikutip Qutb, Abu Bakar al-Shiddiq r.a., khalifah pertama dan sahabat Rasulullah saw., seusai pembaiatannya sebagai khalifah, dalam khotbahnya antara lain mengatakan: "Amma ba'du, hai kaum Muslimin, aku telah diangkat sebagai penguasa kalian, padahal aku ini bukan orang yang terbaik di antara kalian. Karena itu jika aku berbuat baik bantulah aku dan jika aku berbuat buruk luruskanlah aku"... dan sterusnya, hingga ucapannya yang mengatakan: "Ta'atilah aku selama taat kepada Allah dan Rasul-Nya. Apabila aku berbuat durhaka terhadap Allah dan Rasul-Nya kalian tidak wajib taat kepadaku". Maka menurut Qutb, dengan khotbah yang diucapkannya itu Abu bakar r.a., meletakkan kaidah Islam yang

\section{${ }^{47}$ Ibid}


terpenting dan terpokok mengenai batas-batas kekuasaan menurut Islam. $^{48}$

Di dalam karyanya yang lain, Qutb juga menyinggung sistem politik Islam. Menurut Qutb, sistem politik Islam dibangun di atas dua konsep dasar yang merupakan perpanjangan konsepsinya yang meyneluruh tentang alam, kehidupan dan manusia. Dua konsep dasar tersebut adalam pertama, pemikiran integral tentang jenis manusia, watak dan pertumbuhannya dan kedua, konsep bahwa Islam merupakan satu sistem universal yang abadi bagi masa depan kemanusiaan.

Dalam konsep dasar yang pertama yakni kesatuan manusia dalam jenis, watak dan pertumbuhannya, Qutb menyatakan bahwa hak-hak bagi orang-orang dzimmi dan kaum musyrikin yang terikat perjanjian damai dengan kaum muslimin, betul-betul ditegakkan atas asas kemanusiaan tanpa perbedaan antara pemeluk agama yang satu dengan lainnya apabila ia sampai pada persoalan kebutuhan manusia pada umumnya Kalaulah Islam memerintahkan pemeluknya untuk memerangi kaum musyrikin, maka hal itu merupakan upaya membela diri dari serbuan pihak lain di samping membela kemerdekaan dakwah dan iman. ${ }^{49}$

Sedangkan dalam konsep dasar yang kedua yakni bahwa Islam merupakan satu sistem universal yang abadi bagi masa depan kemanusiaan, Qutb menjelaskan bahwa hal itu muncul dari ketentuan bahwasanya Muhammad SAW. itu adalah utusan bagi seluruh umat manusia. Dia adalah Nabi penutup dan agamanya adalah agama yang paling sempurna. Dalam kontek ini juga Qutb menjelaskan bahwa Islam memberikan kebebasan penuh kepada agama-agama lain untuk melaksanakan syiar-syiar agamanya. Sementara itu kedalaman perasaan terhadap kemerdekaan dan kebebasan yang diberikannya kepada umat di luar Islam telah mencapai tingkat sedemikian rupa dimana kaum muslim sendiri dikenakan wajib zakat dan bagi ahlu dzimmah dikenakan jizyah itupun diperuntukkan pula bagi pembiyaan kebutuhan-kebutuhan mereka. ${ }^{50}$

Bagi Qutb, sistem Islam yang dibangun atas dua konsep ini mempunyai pengaruh terhadap inti konsep dan arah yang

\footnotetext{
${ }^{48}$ Ibid., h. 96

${ }^{49}$ Sayyid Qutb, al- 'Adalah, h. 126-127

${ }^{50}$ Ibid., h. 128
} 
ditempuhnya, yang dijadikannya sebagai titik perhatian dalam pelaksanaan syari'at dan arah yang ditempuhnya; dalam politik pemerintahan, politik kepemilikan dan seluruh sistem yang tercakup di dalamnya. Islam tidak menetapkan syari'at berdasar atas ras dan kasta, melainkan bagi semua manusia dan lapisan masyarakat. Islam selanjutnya menetapkan asas manusia yang bersifat komprehensif dalam syari'at dan sistemnya, lalu Islam meletakkan kaidah yang bersifat umum dan prinsip-prinsip yang luas, yang utuk selanjutnya membiarkan semua ini berkembang mengikuti zaman dan tuntutan kebutuhan manusia. ${ }^{51}$

Secara spesifik, Qutb juga menjelaskan bahwa politik pemerintahan dalam Islam dibangun atas beberapa asas antara lain; pertama, keadilan penguasa, kedua, ketaatan rakyat dan ketiga, permusyawaratan antara penguasa dan rakyat. Beberapa asas ini menurut Qutb merupakan garis-garis besar yang bersifat mendasar yang darinya nanti akan muncul berbagai cabang permasalahan. Dalam menjelaskan asas pertama yakni keadilan penguasa, Qutb mendasarkan pandangannya pada beberapa ayat al-Qur'an antara lain; "Sesungguhnya Allah memerintah kamu untuk berlaku adil ..." (QS. 16: 90), "dan apabila kamu menetapkan hukum di antara manusia, supaya kamu menetapkan dengan adil ..." (QS. 4: 58), "dan apabila kamu berkata hendaklah kamu berlaku adil, kendatipun ia adalah kerabatmu sendiri ..” (QS. 6:152), “dan hendaklah jangan sekali-kali kebencian kepada sesuatu kaum, mendorong kamu untuk berlaku tidak adil. Berlaku adillah karena hal itu lebih dekat kepada takwa..." (QS. 5: 8).

Sebagai asas pertama, keadilan penguasa menurut Qutb adalah keadilan yang mutlak yang tidak akan miring keputusannya karena terpengaruh oleh perasaan cinta maupun benci yang tidak dapat merubah kaidahnya karena adanya suka dan tidak suka; suatu keadilan yang tidak terpengaruh oleh hubungan kerabat antara berbagai individu dan tidak terpengaruh oleh hubungan kerabat antara berbagai individu dan tidak pula oleh perasaan benci antara suku. Di sini setiap individu menikmati keadilan yang sama, tidak ada diskriminasi antara mereka yang muncul karena nasab dan kekayaan, karena uang dan pangkat sebagaimana yang ada pada umat di luar Islam, walaupun antara kaum muslimin dan orangorang non-Muslim itu terdapat permusuhan dan kebencian.

${ }^{51}$ Ibid., h. 129 
Sungguh ini merupakan nilai keadilan yang belum pernah dicapai oleh Hukum Internasional manapun dan juga oleh hukum lokal manapun sampai detik ini. ${ }^{52}$ Keadilan sebagai asas pertama nampaknya lebih mengarah pada penghapusan diskriminasi baik menyangkut status ekonomi maupun agama.

Sementara itu dalam menjelaskan asas kedua tentang ketaatan rakyat, Qutb mendasarkan pada sebuah ayat al-Qur'an "Wahai orang-orang yang beriman, taatilah Allah dan Rasul-Nya dan orang-orang yang memegang kekuasaan di antara kamu..." (QS. 4: 59). Menurut Qutb, ketaatan kepada para pemegang kekuasaan merupakan perpanjangan dari ketaatan kepada Allah dan RasulNya, sebab menaati Waliul Amri dalam Islam bukanlah karena jabatan mereka, tetapi karena pelaksanaan syari'at Allah dan Rasul-Nya yang mereka tegakkan dan pelaksanaan syariat yang bersumber dari Allah dan Rasul-Nya ini berhak untuk ditaati. Jadi bila ia menyimpang dari garis-garis yang telah ditetapkan Allah dan Rasul-Nya, maka gugurlah kewajiban taat itu dan segala perintahnyapun tidak wajib dilaksanakan. ${ }^{53}$

Tidak seperti pemikir Islam sebelumnya yang karena hanya berhenti pada ayat tentang perintah taat pada penguasa hingga menganggap penguasa merupakan bayangan Tuhan, Qutb nampaknya lebih selektif. Bagi pemikir sebelumnya, siapa yang mentaati penguasa akan mendapatkan pahala dan siapa yang tidak mentaatinya dianggap telah melanggar perintah agama. Semua ini berbeda dengan Qutb, dimana bagi Qutb ketaatan rakyat kepada penguasa hanya diwajibkan manakala sang penguasa masih mentaati dan menjalankan undng-undang Tuhan. Namun jika penguasa sudah menyeleweng dari hukum Tuhan, maka gugurlah ketaatan itu.

Qutb juga bersandar pada sebuah hadis; "Setiap individu muslim, suka atau tidak, wajib patuh dan taat terhadap ketentuan yang telah ditetapkan, kecuali bila diperintah untuk melakukan kemaksiatan. Maka bila ia diperintah untuk melakukan kemaksiatan, tidak ada ketaatan dan kepatuhan baginya. Hadis lain yang juga dirujuk oleh Qutb adalah; "Dengar dan taatilah, sekalipun yang memerintahkan kepadamu itu seorang hamba negro yang botak kepalanya sepanjang ia memerintah kepadamu dengan

${ }^{52}$ Ibid., h. 130

TAJDID Vol. XIV, No. 1, Januari-Juni 2015163 
berpijak pada Kitabullah". Dengan mendasarkan pada dua hadis ini, maka kembali Qutb menegaskan bahwa ketaatan dan kepatuhan itu terbatas hanya pada pelaksanaan Kitabullah. Ketaatan ini bukanlah ketaatan mutlak kepada penguasa dan bukan pula ketaatan tanpa reserve sekalipun penguasanya meninggalkan syari'at Allah dan Rasul-Nya. ${ }^{54}$

Bagi Qutb, seorang penguasa Islam sama sekali tidak memiliki kekuasaan keagamaan yang diterimanya dari langit sebagaimana yang pernah dimiliki oleh penguasa pada sementara agama tempo dulu. Ia menjadi penguasa semata-mata karena dipilih oleh kaum muslimin berdasar kebebasan hak mereka yang mutlak sempurna, tanpa adanya ikatan perjanjian dengan penguasa sebelumnya ataupun sebagai warisan dari keluarganya. Selanjutnya ia harus meneruskan kekuasaan yang diperolehnya melalui cara itu dengan melaksanakan syari'at Allah. Jadi apabila kaum muslimin tidak rela diperintah olehnya, maka kekuasaan itupun tidak lagi berada di tangannya, dan begitu pula bila seandainya ia menyimpang dari syariat Allah, sekalipun kaum muslimin rela menerimanya sebagai penguasa.

Oleh karena beberapa hal tersebut maka Qutb menegaskan bahwa semua bentuk pemerintahan yang melaksanakan syari'at Islam dapat disebut sebagai pemerintahan Islam, apapun juga bentuk dan gambaran pemerintahan itu. Sebaliknya semua bentuk pemerintahan yang tidak seperti itu, yang tidak mengakui Islam --sekalipun ia dilaksanakan oleh suatu organisasi yang menamakan dirinya Islam atau mempergunakan label Islam. Dengan demikian Qutb kembali menegaskan bahwa ketaatan rakyat hanyalah terbatas dan terikat pada pelaksanaan syari'at Islam semata, tanpa persyaratan lain yang tidak adil dalam pemerintahan dan ketaatan kepada Allah. ${ }^{55}$

Akhirnya dalam menjelaskan asas ketiga yakni musyawarah antara penguasa dan rakyat, Qutb bersandarkan pada ayat; “... dan bermuyawarahlah dengan mereka dalam urusan ini ..." (QS. 3:159), demikian juga ayat "...dan urusan mereka diputuskan dengan jalan musyawarah antara mereka..." (QS. 42: 38). Namun demikian, dalam keterangannya Qutb menjelaskan bahwa permusyawaratan merupakan salah satu prinsip di antara prinsip-

\footnotetext{
${ }^{54}$ Ibid., h. 131-132

${ }^{55}$ Ibid., h. 133
} 
prinsip pemerintahan Islam, sedangkan teknisnya menurutnya secara spesifik tidak ditentukan. Oleh karenanya menurut Qutb bentuk musyawarah itu menyesuaikan dengan kepentingan dan kebutuhan, alias sesuai dengan situasi dan kondisi. Adapun salah contoh yang diberikan oleh Qutb adalah musyawarah yang dilakukan oleh Nabi dengan para sahabat menyangkut persoalan yang jawabannya tidak diberikan oleh wahyu dan mengambil pendapat mereka yang lebih tahu khususnya dalam masalahmaslaah duniawi semisla strategi perang dan sebagainya. ${ }^{56}$ Qutb nampaknya belum merumuskan lebih rinci bagaimana mekanisme dan sistem permusyawaratan itu manakala sebuah negara Islam telah terbentuk. Contoh yang dicantumkan Qutb, yakni musyawarah $\mathrm{Nab}$ dengan para sahabatnya bisa dibilang masih sederhana.

\section{Penutup}

Demikianlah tiga asas politik pemerintahan Islam. Pada akhirnya Qutb menjelaskan bahwa politik pemerintahan dalam Islam dibangun di atas asas yang bersumber dari hati nurani, lebih dari sekedar dibangun di atas asas syari'at. Ia dibangun atas asas bahwa Allah SWT. selalu hadir setiap saat di sisi para penguasa dan rakyat mengawasi segala sesuatunya. Namun demikian, tidak bisa juga dipahami bahwa sistem sosial Islam hanya dibangun atas asas yang bersumber dari hati nurani saja. Akan tetapi yang mesti dipahami adalah bahwa dalam Islam terdapat jaminan lain selain yang ditetapkan melalui syara'. Inilah yang membuatnya berbeda dengan sistem-sistem lain yang semata-mata didasarkan atas undang-undang belaka, tanpa dukungan jaminan yang keluar dari hati nurani dan perasaan. ${ }^{57}$ Pesan moral Qutb ini bukan tanpa alasan. Sasarannya barangkali adalah bahwa meskipun sebuah negara dijalankan berdasarkan syari'at Islam, tetapi jangan kemudian pelaksanaan hukum dan syari'at itu lepas sama sekali dari pertimbangan nurani.

\section{Daftar Pustaka}

Abd. Al-Salah, al-Khalidi, Sayyid Qutb al-Syahid al-Hayy (Amman: Maktabat al-Aqsha, 1981), h. 89

\footnotetext{
${ }^{56}$ Ibid

${ }^{57}$ Ibid., h. 138-139
} 
Adnan A. Musallam, "Sayyid Qutb and Social Justice", dalam Journal of Islamic Studies (Januari, 1993), vol. 4, h. 56

al-Ghazali, Zainab. Perjuangan Wanita Ikhwanul Muslimin, terj. Jakarta: Gema Insani Press, 1993.

al-Khiladi, Shalah Abd. Al-Fattah. Sayyid Qutb al-Syahid al-Hayy, Amman: Maktabat al-Aqsha, 1981.

Barakat, Muhammad Tawfiq. Sayyid Qutb: Khulâshah Hayâtuh, Minhajuh fì al-Harakah, al-Naqd al-Muwajjah Ilaih, Mekah: Maktabah al-Munarah, tt.

Fadhlullah Mahdi, Ma'a Sayyid Qutb fi Fikri al-Siyasi wa al-Dini, Kairo: Dar al-Da'wat, 1978.

Haddad, Yvone Y. "Sayyid Qutb: Ideogue of Islamic Revival" dalam John L. Esposito (ed) Voice of Resurgent Islam, New York: Oxford University Press, 1983.

Qutb, Muhammad, Sukhriyyât Shaghîrat, Beirut: Dar al-Lubnah, tt.

Qutb, Sayyid et. al., al-Atyâf al-Arba'ah, Beirut: Dar al-Lubnah, 1967.

------, Masyâhid al-Qiyâmah fî al-Qur'ân, Beirut: Dar al-Syuruq, 1976.

------, al-'Adalah al-Ijtima'iyyah fi al-Islam, Dar al-Khatib al'Arabi, tt.

------, "Hasan al-Bannâ wa "Abqariyyât al-Binâ", dalam Dirâsat Islâmiyyat, Beirut: Dar al-Syuruq, 1982.

------, Fi Dzilal al-Qur'an, Makkah: Dar al-'Ilmi Li’ Thiba'ah, 1986.

------, Al-Salam al-'Alami wa al-Islam, Beirut: Dar al-Syuruq, 1983.

Sulaiman, al-Usymawi Ahmad. al-Syâhid Sayyid Qutb, Kairo: Dar al-Da'wat, 1969.

Salabi, Ahmad. Mausû'at al-Târîkh al-Islâmî wa al-Hadlârat alIslâmiyyat, Kairo: Maktabat al-Nahdhat al-Mishriyyah, 1972.

Shahrough Akhavi, "Sayyid Qutb" dalam John L. Esposito (ed), The Oxford Encyclopedia of the Modern Islamic World, vol. III, New York: Oxford University Press, 1995.

Watt, W. Montgomery. Islamic Fundamentalism and Modernity, London: Routledge, 1988. 